Sains Malaysiana 49(1)(2020): 43-48

http://dx.doi.org/10.17576/jsm-2020-4901-05

\title{
Essential Oil Constituents of Alpinia scabra and Alpinia murdochii, Two Wild Highland Species from Peninsular Malaysia and Their Anti-Microbial Activity (Komposisi Minyak Pati Alpinia scabra dan Alpinia murdochii, Dua Spesies Liar dari Semenanjung Malaysia dan Aktiviti Anti-Mikrobnya)
}

\section{Devi Rosmy Syamsir, Norsita Tohar, Halijah Ibrahim, Nor Azah Mohamad Ali, Mastura Mokhtar, Yasodha Sivasothy \& KhaliJah Awang*}

\section{ABSTRACT}

This study investigates the chemical constituents of essential oils and their anti-microbial activity of Alpinia scabra and Alpinia murdochii, two wild Zingiberaceae species. The essential oils were obtained by hydrodistillation and the chemical components of the oils were determined by GC-FID (retention indices, RI) and GC/MS analysis. The major components of Alpinia scabra rhizome oil are $\gamma$-selinene (33.45\%), $\alpha$-selinene (3.64\%) and $\alpha$-terpineol (3.55\%) while the major components of the leaves are $\beta$-pinene (63.37\%), $\alpha$-pinene (6.58\%) and borneol (3.20 \%). The major compounds of Alpinia murdochii rhizome oil are $\gamma$-selinene (15.51\%), (E,E)-farnesyl acetate (6.56\%), terpinen 4-ol $(5.58 \%)$ and $\alpha$-terpineol $(5.04 \%)$. The monoterpenes; $\beta$-pinene $(23.83 \%)$, sabinene $(23.76 \%)$ and terpinene-4-ol $(10.49 \%)$ were the major components in the leaf oil of A. murdochii. The lowest MIC values were recorded for the rhizome essential oils of both Alpinia species against all Staphylococcus aureus strains (coded as MSSA, MRSA, Sa7, VISA24, VRSA156) with MIC values ranging from $0.04 \mathrm{mg} / \mathrm{mL}$ to $2.50 \mathrm{mg} / \mathrm{mL}$. The rhizome oils of both species also showed a broad spectrum of anti-microbial activity as compared to the leaf oils.

Keywords: Anti-microbial agent; hydrodistillation; lengkuas; $\gamma$-selinene

ABSTRAK

Penyelidikan ini mengkaji kandungan kimia minyak pati dan aktiviti anti-mikrob Alpinia sabra dan Alpinia murdochii, dua spesies liar daripada keluarga Zingiberaceae. Minyak pati yang diperoleh melalui penyulingan hidro dan komponen kimia kedua-dua minyak pati tersebut ditentukan menggunakan analisis kromatografi gas (GC-FID) (indeks pengekalan, RI) dan kromatografi gas/spektrometri jisim. Komponen utama dalam minyak pati rizom A. scabra adalah $\gamma$-selinen (33.45\%), $\alpha$-selinene (3.64\%) dan $\alpha$-terpineol (3.55\%) sementara komponen dalam minyak pati daun A. scabra adalah $\beta$-pinene (63.37\%), $\alpha$-pinene (6.58\%) dan borneol (3.20\%). Komponen kimia di dalam minyak pati rizom A. murdochii pula adalah $\gamma$-selinen (15.51\%), (E,E)-farnesyl acetate (6.56\%), terpinen 4-ol (5.58\%) dan $\alpha$-terpineol (5.04\%). Monoterpene, $\beta$-pinene (23.83\%), sabinene (23.76\%) dan terpinene-4-ol (10.49\%) merupakan kandungan utama dalam minyak pati daun A. murdochii. Bacaan nilai MIC terendah dicatatkan oleh minyak pati rizom kedua-dua spesies Alpinia terhadap semua strain Staphylococcus aureus (dikodkan sebagai MSSA, MRSA, Sa7, VISA24, VRSA156) dengan nilai MIC antara $0.04 \mathrm{mg} / \mathrm{mL}$ ke $2.50 \mathrm{mg} / \mathrm{mL}$. Minyak pati rizom kedua-dua spesies juga menunjukkan spektrum antimikrob yang luas berbanding minyak pati daun.

Kata kunci: Agen anti-mikrob; lengkuas; penyulingan hidro; $\gamma$-selinen

\section{INTRODUCTION}

Alpinia is one of the largest genus of the family Zingiberaceae with more than 250 species in tropical regions. The rhizomes of several species are useful in folk medicine and as alternative treatment for certain illnesses. Alpinia conchigera, for example, is traditionally used to treat fungal infection (Ibrahim et al. 2000) and can be consumed as a post-partum medicine (Ibrahim et al. 2009). Alpinia galanga is used as treatment for stomach ache, diarrhea and it is a carminative and anti-microbial agent (Oonmetta-Aree et al. 2006). This species is also used in the preparation and flavouring of culinary dishes. In Malaysia it is known by the local name lengkuas and it is also used as condiment and spice in many countries of Asia. Several other species of Alpinia are valued as ornamentals due to their beautiful orchid like flowers such as $A$. purpurata, A. zerumbet and $A$. mutica.

Alpinia scabra and Alpinia murdochii are two wild Zingiberaceae species from the highlands of Pahang, Malaysia. According to Burkill, 1935, a hot water fomentation is made with $A$. scabra, or heated leaves are applied to the abdomen to treat vertigo. Our previous study 
on this species showed that the hexane and dichloromethane extracts of the leaves and rhizomes showed very good cytotoxic effect against ovarian cancer cell line (SKOV-3) and the dichloromethane extract of the leaves also showed high inhibitory effect against breast carcinoma cell line (MCF-7) (Ibrahim et al. 2010).

To the best knowledge of our knowledge, no studies have been done on the constituents of the essential oils from both species. Therefore, in this study, we shall communicate the chemical constituents of the essential oils of the two wild Alpinia species collected from Genting Highland, Pahang, namely Alpinia scabra and Alpinia murdochii and their anti-microbial activities.

\section{Materials AND Methods}

\section{PLANT MATERIAL}

The fresh leaves and rhizomes of Alpinia scabra and Alpinia murdochii (herbarium no: HI 1419 and HI 1420, respectively) were collected from Genting Highland, Pahang and authenticated by Professor Dr. Halijah Ibrahim. Voucher specimens were deposited in the herbarium of Institute of Biological Sciences, University of Malaya.

\section{EXTRACTION OF THE ESSENTIAL OILS}

Fresh samples of leaves and rhizomes were immediately washed, cut into small pieces and air dried for 3 days consecutively. Then, the samples were ground into small pieces and hydrodistilled using a Clevenger type apparatus for $8 \mathrm{~h}$. The oil was dried over sodium sulfate anhydrous and stored in a sealed vial at $4^{\circ} \mathrm{C}$ until further analysis.

\section{GAS CHROMATOGRAPHY - FLAME IONIZATION DETECTOR (GC-FID)}

GC analysis was performed using a Shimadzu GC-2010 capillary chromatograph equipped with a flame ionization detector using fused silica capillary column CBP-5 (25 m $\times 0.22 \mathrm{~mm}$ i.d, $0.25 \mu \mathrm{m}$ film thickness). The samples were dissolved in hexane and injected in split mode (20:1). The operating parameters were; helium as carrier gas at a linear velocity of $50 \mathrm{cc} / \mathrm{min}$, injector and detector temperature at $250^{\circ} \mathrm{C}$. The column was programmed initially at $60^{\circ} \mathrm{C}$ for $10 \mathrm{~min}$, then to $230^{\circ} \mathrm{C}$ at $3^{\circ} \mathrm{C} / \mathrm{min}$ and finally held at $230^{\circ} \mathrm{C}$ for $10 \mathrm{~min}$.

\section{GAS CHROMATOGRAPHY-MASS SPECTROMETRY (GC/MS)}

GC/MS analysis was performed using a $6890 \mathrm{~N}$ Network GC System equipped with a 7683 Series auto-injector coupled to a 5975 Inert Mass Selective Detector and the same capillary GC conditions as described above. Carrier gas used was helium. Significant MS operating parameters: ionization voltage, $70 \mathrm{eV}$; ion source temperature $230^{\circ} \mathrm{C}$; mass range 50-600 amu.

\section{IDENTIFICATION OF CONSTITUENTS}

The constituents of the oils were identified by matching their mass spectra with those from MS Libraries NIST 0.5L, and confirmed by comparison of retention indices (RI) with data in the literature (Adam 2001; Tohar et al. 2006a, 2006b). RI was determined with a standard mixture of homologous series of alkane $\left(\mathrm{C}_{7}-\mathrm{C}_{25}\right)$ under the same chromatographic conditions used when analyzing the oils. The relative percentage of the oil constituents was expressed as percentage by peak area normalization without the use of correction factors.

\section{ANTI-MICROBIAL ACTIVITY}

The essential oils were individually tested against five strains of Staphylococcus aureus namely Methicillin sensitive Staphylococcus aureus ATCC 29213 (MSSA), Methicillin resistant S. aureus ATCC 33591 (MRSA), Vancomycin intermediate resistant $S$. aureus ATCC 700699 (Sa7), MRSA with intermediate resistance to vancomycin (VISA24) and MRSA with complete resistance to vancomycin (VRSA156), two candida; Candida albicans (ATCC 10231) and Candida glabrata (ATCC 64677), two dermatophytes, Microsporum canis (ATCC 36299) and Trichophyton rubrum (ATCC 28188). All isolates were purchased from American Type Culture Collection (ATCC) except two mutant isolates namely VISA24 and VRSA156 that were obtained through a step wise lab-passage procedure as described previously (Mohtar et al. 2009).

Media was sterilized by autoclaving at $120^{\circ} \mathrm{C}$ for 15 min and all subsequent manipulations were carried out in a class 2 biohazard cabinet. The Staphylococcus aureus strains (coded as MSSA, MRSA, Sa7, VISA24 and VRSA156) were cultured in Mueller Hinton Broth (MHB), VISA and VRSA in tryptic soy broth (TSB) overnight (24 h) at $37^{\circ} \mathrm{C}$ while the candida and dermatophytes were cultured in potato dextrose broth (PDB) overnight at $26^{\circ} \mathrm{C}$. The resulting inoculum was further adjusted to obtain turbidity comparable to that of McFarland standard tube No. 0.5 (Vandepitte et al. 1991) prior to use.

The minimum inhibitory concentration (MIC) value determination assay was carried out to evaluate the compounds which maybe potential as inhibitory agents against test isolates using double-broth micro-dilution method involving 96-wells microtitre-plates as described previously (Saiful et al. 2008). Briefly, serial two-fold dilutions of the test compounds dissolved in DMSO were prepared prior to addition of $100 \mu \mathrm{L}$ overnight microbial suspension $\left(10^{8} \mathrm{CFU} / \mathrm{mL}\right)$ followed by incubation at $37^{\circ} \mathrm{C}$ (bacteria) or $26^{\circ} \mathrm{C}$ (dermatophytes and candida) for $24 \mathrm{~h}$. The highest concentration of DMSO remaining after dilution $(5 \%, \mathrm{v} / \mathrm{v})$ caused no inhibition of bacterial/candida/ dermatophytes growth. Antibiotic cycloheximide was used for anti-candida and anti-dermatophyte comparison while oxacillin was used for anti-bacterial testing. DMSO served as negative control. 
Turbidity was taken as indication of growth, thus the lowest concentration which remains clear after macroscopic evaluation was taken as the minimum inhibitory concentration (MIC). For further reconfirmation, $20 \mu \mathrm{L}$ of MTT reagent $(1 \mathrm{mg} / \mathrm{mL})$ was added to the suspension in the selected wells, followed by $20 \mathrm{~min}$ incubation at $37^{\circ} \mathrm{C}$. The reagent-suspension colour will remain clear/yellowish indicating complete inhibition (cidal) activity as opposed to the dark blue colour for growth (Eloff 1998). The MIC was recorded as the most repeatable minimum concentration of triplicates done in one experiment.

\section{RESUlTS AND DisCUSSION}

\section{COMPOSITION OF THE ESSENTIAL OIL}

The dried leaves and rhizomes of Alpinia scabra and Alpinia murdochii were subjected to hydrodistillation using Clevenger-type apparatus. The yield of the oils of Alpinia scabra (leaves and rhizomes) are $0.16 \%$ and $0.02 \%$, respectively, while the yield of Alpinia murdochii oils (leaves and rhizomes) are $0.48 \%$ and $0.09 \%$, respectively. Table 1 lists the comparison of the oil components from both species with their retention indices and the relative GC peaks areas of these constituents on the CBP-5 capillary column. Forty components of Alpinia scabra leaf oil were identified and comprising of $86.61 \%$ of the total oil. This oil could be a good source of $\beta$-pinene as it made up to $63.37 \%$ of the total oils. Additionally, other major compounds were $\alpha$-pinene $(6.58 \%)$, borneol $(3.20 \%)$, caryophyllene oxide (1.69\%), p-cymen-8-ol (1.20\%), trans-pinocarveol (1.15\%), myrtenyl acetate $(1.03 \%)$ and limonene (1.0\%). Hydrocarbons formed the most abundant group in this oil with 13 compounds accounting for $73.02 \%$ of the total leaf oils. The constituents of the A. scabra rhizome oils contained more than fifty compounds; however only 41 components were detected comprising of $70.96 \%$ of the total oil. GC and GC/MS analyses showed that the major compounds of the oils were $\gamma$-selinene (33.45\%), $\alpha$-selinene $(3.64 \%), \alpha$-terpineol $(3.55 \%)$, $\gamma$-muurolene $(3.45 \%)$, alloaromadendrene $(3.32 \%)$ and spathulenol (3.25\%).

The chemical constituents of the leaf of Alpinia murdochii was identified with forty compounds amounting to $94.31 \%$ of the total oils. The oils were dominated by 17 hydrocarbons representing $72.56 \%$. Twelve compounds of this group are monoterpenes and five compounds belong to sesquiterpenes. The monoterpenes; $\beta$-pinene and sabinene were the major components $(23.83 \%$ and $23.76 \%$ respectively). Sabinene was known to impart a woody odour (Moon et al. 2006) and $\beta$-pinene was reported to emit turpentine like odour (de Pooter et al. 1985). A total of 37 compounds were identified from the Alpinia murdochii rhizome oils which make up to $71.06 \%$ of area percent. This oil showed a high content of sesquiterpene hydrocarbons $(26.85 \%)$ and oxygenated monoterpenes $(19.56 \%)$. Other compounds are oxygenated non-terpenes $(9.57 \%)$, monoterpene hydrocarbons $(8.56 \%)$, oxygenated sesquiterpenes $(3.05 \%)$, non-terpene hydrocarbons $(2.70 \%)$

TABLE 1. Essential oil constituents of the leaves and rhizomes of Alpinia scabra and Alpinia murdochii

\begin{tabular}{|c|c|c|c|c|c|}
\hline \multirow{3}{*}{ Compounds } & \multirow{3}{*}{ RI } & \multicolumn{4}{|c|}{ Composition (\%) ${ }^{a}$} \\
\hline & & \multicolumn{2}{|c|}{ Alpinia scabra } & \multicolumn{2}{|c|}{ Alpinia murdochii } \\
\hline & & Leaf & Rhizome & Leaf & Rhizome \\
\hline Furfural & 836 & 0.12 & 0.41 & - & 0.82 \\
\hline 3-Hexenol & 851 & 0.55 & 0.08 & 0.06 & - \\
\hline$\alpha$-Thujene & 929 & - & - & 3.54 & - \\
\hline$\alpha$-Pinene & 937 & 6.58 & 0.19 & 8.56 & 0.76 \\
\hline Camphene & 949 & 0.44 & - & 0.11 & - \\
\hline Sabinene & 974 & - & - & 23.76 & - \\
\hline$\beta$-Pinene & 979 & 63.37 & 0.21 & 23.83 & 2.80 \\
\hline Myrcene & 983 & - & - & 0.16 & - \\
\hline$\alpha$-Phellandrene & 1002 & - & - & 0.06 & - \\
\hline$\alpha$-Terpinene & 1016 & - & - & 1.91 & 1.26 \\
\hline$\delta$-2-Carene & 1024 & 0.10 & - & - & - \\
\hline$p$-Cymene & 1026 & - & - & 3.83 & 2.66 \\
\hline Limonene & 1028 & 1.00 & 0.69 & - & 0.31 \\
\hline$\beta$-Phellandrene & 1029 & - & - & 1.51 & - \\
\hline$\delta$-3-Carene & 1030 & - & - & 1.04 & - \\
\hline 1,8-Cineol & 1054 & 0.08 & - & - & - \\
\hline$\gamma$-Terpinene & 1057 & 0.12 & - & 4.25 & 0.77 \\
\hline $\begin{array}{l}\text { cis-Sabinene } \\
\text { hydrate }\end{array}$ & 1064 & - & - & 0.49 & - \\
\hline $\begin{array}{l}\text { trans-Sabinene } \\
\text { hydrate }\end{array}$ & 1078 & - & - & 1.11 & 0.28 \\
\hline $\begin{array}{l}\text { 3,5,5-trimethyl } \\
\text { 2-cyclopenten- } \\
\text { 1- one }\end{array}$ & 1107 & 0.06 & - & - & - \\
\hline Exo-fenchol & 1123 & 0.13 & 1.46 & - & - \\
\hline$\alpha$-Campholenal & 1123 & - & - & 1.08 & 0.63 \\
\hline Nopinone & 1134 & 0.20 & 0.13 & 1.29 & - \\
\hline $\begin{array}{l}\text { trans- } \\
\text { Pinocarveol }\end{array}$ & 1140 & 1.15 & 0.23 & 0.41 & 1.99 \\
\hline $\begin{array}{l}\text { Benzene } \\
\text { acetaldehyde }\end{array}$ & 1134 & - & 0.66 & - & - \\
\hline Camphor & 1144 & 0.14 & - & - & - \\
\hline Sabina ketone & 1155 & - & 0.99 & 0.36 & 1.07 \\
\hline Isoborneol & 1147 & 0.11 & - & - & - \\
\hline Pinocarvone & 1156 & 0.63 & 1.16 & 0.08 & 0.98 \\
\hline Borneol & 1165 & 3.20 & 0.14 & 0.54 & 0.45 \\
\hline
\end{tabular}




\begin{tabular}{|c|c|c|c|c|c|}
\hline Pinocamphone & 1171 & 0.38 & - & - & - \\
\hline Terpinen- 4-ol & 1176 & 0.07 & 0.29 & 10.49 & 5.58 \\
\hline p-Cymen-8-ol & 1183 & 1.20 & 0.14 & 1.56 & - \\
\hline$\alpha$-Terpineol & 1201 & 0.44 & 3.55 & 0.46 & 5.04 \\
\hline Myrtenal & 1201 & - & 2.30 & - & 1.99 \\
\hline Myrtenol & 1209 & 0.07 & 0.45 & 0.82 & 0.72 \\
\hline cis-Piperitol & 1211 & - & - & 0.31 & - \\
\hline Verbenone & 1216 & - & 0.1 & - & 0.33 \\
\hline cis-Carveol & 1222 & - & - & 0.12 & - \\
\hline Cumin aldehyde & 1237 & - & - & 0.27 & - \\
\hline $\begin{array}{l}\text { 2-Methyl-3-phenyl } \\
\text { propanal }\end{array}$ & 1237 & - & - & - & 0.61 \\
\hline Perilla aldehyde & 1275 & 0.23 & - & - & - \\
\hline Bornyl acetate & 1283 & - & - & 0.35 & - \\
\hline Carvacrol & 1284 & - & - & - & 0.56 \\
\hline Perilla alcohol & 1304 & - & - & 0.28 & - \\
\hline trans-Pinocarvyl acetate & 1310 & 0.23 & - & - & - \\
\hline Myrtenyl acetate & 1322 & 1.03 & - & - & - \\
\hline p-Mentha-1,4-dien7-ol & 1331 & - & - & - & 0.40 \\
\hline$\alpha$-Copaene & 1377 & 0.07 & 0.1 & 0.06 & 1.48 \\
\hline$\beta$-Elemene & 1377 & - & 0.35 & - & - \\
\hline (Z)- Caryophyllene & 1407 & - & - & 0.06 & 1.64 \\
\hline (E)-Caryophyllene & 1418 & 0.19 & 0.07 & 0.41 & - \\
\hline$\alpha$-Lonone & 1423 & 0.14 & - & - & - \\
\hline$\beta$-Selinene & 1448 & - & - & - & 0.32 \\
\hline$\alpha$-Selinene & 1472 & - & - & - & 1.79 \\
\hline$\alpha$-Selinene & 1471 & 0.17 & 3.64 & - & 2.30 \\
\hline Pentadecane & 1481 & 0.09 & - & - & - \\
\hline$\beta$-Bisabolene & 1507 & 0.42 & 0.39 & - & - \\
\hline$\delta$-Cadinene & 1507 & - & - & 0.12 & - \\
\hline$\alpha$-Panasinsen & 1519 & - & 2.21 & - & 1.22 \\
\hline$\beta$-Sesquiphellandrene & 1521 & 0.07 & - & - & - \\
\hline$\alpha$-Maaliene & 1527 & - & 0.55 & - & 2.59 \\
\hline$\alpha$-Calacorene & 1540 & - & 0.11 & - & 1.51 \\
\hline Elemol & 1547 & - & 0.48 & - & - \\
\hline $\begin{array}{l}\text { trans- } \alpha \text { - Bisabolene } \\
\text { epoxide }\end{array}$ & 1552 & - & 0.40 & - & \\
\hline trans-Nerolidol & 1553 & 0.07 & 0.54 & 0.13 & - \\
\hline Caryophyllene alcohol & 1565 & - & 0.50 & - & - \\
\hline $\begin{array}{l}\text { Caryophyllene } \\
\text { oxide }\end{array}$ & 1574 & 1.69 & - & 0.27 & - \\
\hline Caryophylladienol I & 1638 & 0.24 & - & - & - \\
\hline$\alpha$-Eudesmol & 1643 & - & 2.17 & 0.13 & - \\
\hline$\beta$ - Eudesmol & 1650 & - & 0.46 & 0.12 & - \\
\hline$\gamma$-Gurjunene & 1656 & 0.40 & - & - & - \\
\hline$\gamma$-Selinene & 1665 & - & 33.45 & 0.08 & 15.51 \\
\hline Alloaromaadendrene & 1668 & - & 3.32 & - & - \\
\hline
\end{tabular}

\begin{tabular}{lccccc}
\hline Heptadecane & 1669 & - & - & - & 2.70 \\
$\beta$-Bisabolol & 1671 & - & - & - & 2.40 \\
$\alpha$-Bisabolol & 1677 & 0.36 & - & - & - \\
(E, Z) - Farnesol & 1750 & - & 0.33 & - & 0.65 \\
Benzyl benzoate & 1760 & - & 0.64 & - & 0.77 \\
$\begin{array}{l}\text { E, E)- Farnesyl } \\
\text { acetate }\end{array}$ & 1833 & 0.13 & - & - & 6.56 \\
Phytol & 1915 & 0.98 & - & 0.29 & 0.77 \\
Total & 86.65 & 70.96 & 94.31 & 71.06 & \\
\hline
\end{tabular}

RI; Retention indices calculated on CBP-5 column, ${ }^{\text {a Percentage }}$ of total FID peak area obtained on CBP-5 column

and oxygenated diterpenes $(0.77 \%)$. The major compounds of this oil are $\gamma$-selinene $(15.51 \%),(E, E)$-farnesyl acetate (6.56\%), terpinen 4-ol (5.58\%) and $\alpha$-terpineol (5.04\%).

\section{ANTI-MICROBIAL ACTIVITY}

The leaf and rhizome oils from Alpinia scabra and Alpinia murdochii were tested against five selected strains of Staphylococcus aureus (coded as MSSA, MRSA, Sa7, VISA24, VRSA156) and four selected fungi namely Candida albican, Candida glabrata, Microsporum canis and Trycophytum rubrum. The MIC values of the antimicrobial activities are given in Table 2 with oxacillin and cycloheximide as the positive controls.

The lowest MIC values were recorded from the rhizome oils of both Alpinia species against all $S$. aureus strains with MIC values ranging from 0.04 to $2.50 \mathrm{mg} / \mathrm{mL}$. The rhizome oils also showed a broad spectrum of antimicrobial activity as compared to the leaf oils. Furthermore, the rhizome oils of $A$. scabra and A. murdochii showed an MIC value equivalent to oxacillin $(0.63 \mathrm{mg} / \mathrm{mL})$ against $S$. aureus (Sa7). Rhizome oil of $A$. murdochii exhibited a slightly lower MIC value against VISA24 $(0.08 \mathrm{mg} / \mathrm{mL})$ and VRSA $156(0.04 \mathrm{mg} / \mathrm{mL})$ which is also lower compared to oxacillin $(0.31 \mathrm{mg} / \mathrm{mL})$. Interestingly, VRSA156 showed high inhibition when treated with all essential oils from both species with an MIC value of 0.04 to $0.63 \mathrm{mg} / \mathrm{mL}$. Meanwhile, in this study, the rhizome and the leaf oils showed the same MIC values $(2.50 \mathrm{mg} / \mathrm{mL})$ against all fungi tested.

From our previous study on essential oil of Alpinia pahangensis which also contain $\gamma$-selinene and $\alpha$-terpineol as the major components, showed that the rhizome oil exhibited lower MIC values and the results were comparable to the activity of oxacillin when tested against the same five strains of Staphylococcus aureus used in this study (Awang et al. 2011). The major compound, $\alpha$-terpineol, from rhizomes of $A$. scabra and $A$. murdochii in this study has been reported by Li et al. (2014) to exhibit strong antibacterial activity against Salmonella enteritidis and Staphylococcus aureus with MIC values of 1.56 and 3.13 $\mu \mathrm{g} / \mathrm{mL}$, respectively. Another study by Zhang et al. (2018) showed that terpinen-4-ol exhibit anti-bacterial activity 
TABLE 2. Minimum inhibitory concentration (MIC) values $(\mathrm{mg} / \mathrm{mL})$ of the essential oils of leaf and rhizome of Alpinia scabra and Alpinia murdochii against five strains of Staphylococcus aureus, two candida and two selected dermatophytes fungi

\begin{tabular}{|c|c|c|c|c|c|}
\hline \multirow{3}{*}{ Microorganisms } & \multicolumn{5}{|c|}{$\mathrm{MIC}(\mathrm{mg} / \mathrm{mL})$} \\
\hline & \multicolumn{2}{|c|}{ Alpinia scabra } & \multicolumn{2}{|c|}{ Alpinia murdochii } & \multirow{2}{*}{$\begin{array}{l}\text { References } \\
\text { antibiotic }\end{array}$} \\
\hline & Leaf oil & Rhizome oil & Leaf oil & Rhizome oil & \\
\hline Staphylococcus aureus strains & & & & & Oxacillin \\
\hline ATCC 29213 (MSSA) & 2.50 & 0.63 & 2.50 & 0.63 & $<0.02$ \\
\hline ATCC 33591 (MRSA) & 2.50 & 1.25 & 2.50 & 2.50 & 0.16 \\
\hline ATCC $700699(\mathrm{Sa} 7)$ & 2.50 & 0.63 & 2.50 & 0.63 & 0.63 \\
\hline VISA24 & 2.50 & 0.16 & 1.25 & 0.08 & 0.31 \\
\hline VRSA156 & 0.63 & 0.08 & 0.31 & 0.04 & $<0.02$ \\
\hline Fungal strains & & & & & Cycloheximide \\
\hline Candida albicans (ATCC 10231) & 2.50 & 2.50 & 2.50 & 2.50 & 1.25 \\
\hline Candida glabrata (ATCC 64677) & 2.50 & 2.50 & 2.50 & 2.50 & 1.25 \\
\hline Microsporum canis (ATCC 36299) & 2.50 & 2.50 & 2.50 & 2.50 & 2.18 \\
\hline Trycophyton rubrum (ATCC 28188) & 2.50 & 2.50 & 2.50 & 2.50 & 2.18 \\
\hline
\end{tabular}

Anti-microbial activities were categorized as week (MIC $\geq 5 \mathrm{mg} / \mathrm{mL}$ ), moderate $(1.0<\mathrm{MIC}<4.9 \mathrm{mg} / \mathrm{mL}$ ), or strong (MIC $\leq 1 \mathrm{mg}$ / $\mathrm{mL}$ ); The MIC was recorded as the most repeatable minimum concentration of triplicates done in one experiment

with MIC value of $98 \mu \mathrm{g} / \mathrm{mL}$ against Staphylococcus agalactiae. Terpinen-4-ol was present in leaf and rhizome oils of $A$. scabra and A. murdochii but in higher quantities in the latter. Other than the major compounds, $(E)$ caryophyllene and $\delta$-cadinene, although present in low concentration could account for the anti-microbial activity as they have been associated with anti-bacterial properties (Ali et al. 2017). These findings suggest that the antimicrobial activity exhibited by the rhizome oils of the Alpinia species might be due to the major compounds having a synergistic effect with other minor components.

\section{CONCLUSION}

In conclusion, the rhizome oils of Alpinia scabra and Alpinia murdochii showed comparable inhibition potency as oxacillin which may be due to the presence of known anti-bacterial terpenes such as $\alpha$-terpineol, terpinen-4-ol, $(E)$-caryophyllene and $\delta$-cadinene. To the best of our knowledge, this is the first report to confirm anti-microbial properties of the rhizome essential oils derived from Alpinia scabra and Alpinia murdochii and have potential to be exploited as natural anti-bacterial agents.

\section{ACKNOWLEDGEMENTS}

This project was funded by Sciencefund grant from MOSTI (12-02-03-2070), University of Malaya Postgraduate Research Grant (PPP - PV050/2012A) and University of Malaya Research Grant (UMRG - RP001/2012A).

\section{REFERENCES}

Adam, R. P. 2001. Identification of Essential Oil Components by Gas Chromatography/Quadrupole Mass Spectroscopy. USA: Allured Publishing Corporation.
Ali, N. A. A., Chhetri, B. K., Dosoky, N. S., Shari, K., AlFahad, A. J. A., Wessjohann, L. \& Setzer, W. N. 2017. Antimicrobial, antioxidant and cytotoxic activities of Ocimum forskolei and Teucrium yemense (Lamiaceae) essential oils. Medicines (Basel) 4(2): 17.

Awang, K., Ibrahim, H., Syamsir, D. R., Mohtar, M., Mat Ali, R. \& Mohamad Ali, N. A. 2011. Chemical constituents and anti-microbial activity of the leaf and rhizome oils of Alpinia pahangensis Ridl., an endemic wild ginger from peninsular Malaysia. Chemistry \& Biodiversity 8(4): 668673.

Burkill, I. H. 1935. A Dictionary of the Economic Products of the Malay Peninsula. Volume II. London: Crown Agents for the Colonies.

de Pooter, H. L., Omar, M. N., Coolsaet, B. A. \& Schamp, N. M. 1985. The essential oil of greater galanga (Alpinia galanga) from Malaysia. Phytochemistry 24(1): 93-96.

Eloff, J. N. 1998. A sensitive and quick microplate method to determine the minimal inhibitory concentration of plant extracts for bacteria. Planta Medica 64(8): 711-713.

Ibrahim, H., Sim, K., Syamsir, D., Nor, N. M., Nurestri, A.S. \& Awang, K. 2010. Cytotoxic activity of leaf and rhizome extracts of Alpinia scabra (Blume) Naves, a wild ginger from Peninsular Malaysia. African Journal of Pharmacy and Pharmacology 4(10): 708-711.

Ibrahim, H., Aziz, A. N., Syamsir, D. R., Ali, N. A. M., Mohtar, M., Ali, R. M. \& Awang, K. 2009. Essential oils of Alpinia conchigera Griff. and their anti-microbial activities. Food Chemistry 113(2): 575-577.

Ibrahim, H., Chooi, O. \& Hassan, R. 2000. Ethnobotanical survey of the ginger family in selected Malay villages in Peninsular Malaysia. Malaysian Journal of Science 24: 9396.

Li, L., Shi, C., Yin, Z., Jia, R., Peng, L., Kang, S. \& Li, Z. 2014. Antibacterial activity of alpha-terpineol may induce morphostructural alterations in Escherichia coli. Brazilian Journal of Microbiology 45(4): 1409-1413.

Mohtar, M., Johari, S. A., Li, A. R., Isa, M. M., Mustafa, S., Ali, A. M. \& Basri, D. F. 2009. Inhibitory and resistancemodifying potential of plant-based alkaloids against 
methicillin-resistant Staphylococcus aureus (MRSA). Current Microbiology 59(2): 181-186.

Moon, S. Y., Cliff, M. A. \& Li-Chan, E. C. 2006. Odouractive components of simulated beef flavour analysed by solid phase microextraction and gas chromatographymass spectrometry and-olfactometry. Food Research International 39(3): 294-308.

Oonmetta-Aree, J., Suzuki, T., Gasaluck, P. \& Eumkeb, G. 2006. Anti-microbial properties and action of galangal (Alpinia galanga Linn.) on Staphylococcus aureus. LWTFood Science and Technology 39(10): 1214-1220.

Saiful, A. J., Mastura, M., Zarizal, S., Mazurah, M. I., Shuhaimi, M. \& Ali, A. M. 2008. Efflux genes and active efflux activity detection in Malaysian clinical isolates of methicillinresistant Staphylococcus aureus (MRSA). Journal of Basic Microbiology 48(4): 245-251.

Tohar, N., Awang, K., Mohd, M. A. \& Jantan, I. 2006a. Chemical composition of the essential oils of four Plumeria species grown on Peninsular Malaysia. Journal of Essential Oil Research 18(6): 613-617.

Tohar, N., Mohd, M. A., Jantan, I. \& Awang, K. 2006b. A comparative study of the essential oils of the genus Plumeria Linn. from Malaysia. Flavour and Fragrance Journal 21(6): 859-863.

Vandepitte, J., Engback, K., Piot, P. \& Heuck, C. C. 1991. Basic Microbiology Procedures in Clinical Bacteriology. Geneva: World Health Organization. Volume 85.

Zhang, Y., Feng, R., Li, L., Zhou, X., Li, Z., Jia, R., Song, X., Zou, Y., Yin, L., He, C., Liang, X., Zhou, W., Wei, Q., Du, Y., Yan, K., Wu, Z. \& Yin, Z. 2018. The antibacterial mechanism of terpinen-4-ol against Streptococcus agalactiae. Current Microbiology 75(9): 1214-1220.
Devi Rosmy Syamsir, Norsita Tohar \& Khalijah Awang* Department of Chemistry

Faculty of Science

University of Malaya

50603 KualaLumpur Federal Territory

Malaysia

Halijah Ibrahim

Institute of Biological Sciences

Faculty of Science

University of Malaya

50603 Kuala Lumpur, Federal Territory

Malaysia

Nor Azah Mohamad Ali \& Mastura Mokhtar

Medicinal Plants Programme

Forest Biotechnology Division

Forest Research Institute Malaysia (FRIM)

52109 Kepong, Selangor Darul Ehsan

Malaysia

Yasodha Sivasothy

Research Center for Crystalline Materials

Faculty of Science and Technology

Sunway University

47500 Bandar Sunway, Selangor Darul Ehsan

Malaysia

*Corresponding author; email: khalijah@um.edu.my

Received: 6 August 2019

Accepted: 8 October 2019 